\title{
Increased Oxidative Damage of RNA in Early-Stage Nephropathy in db/db Mice
}

\author{
Wan-Xia Wang, ${ }^{1,2,3}$ Shun-Bin Luo, ${ }^{4}$ Ping Jiang, ${ }^{1}$ Meng-Ming Xia, ${ }^{5}$ Ai-lian Hei, ${ }^{1}$ \\ Yong-Hui Mao, ${ }^{6}$ Chuan-Bao Li, ${ }^{7}$ Guo-Xin $\mathrm{Hu}^{,}{ }^{8}$ and Jian-Ping $\mathrm{Cai}^{1}$ \\ ${ }^{1}$ The MOH Key Laboratory of Geriatrics, Beijing Hospital, National Center of Gerontology, Beijing 100730, China \\ ${ }^{2}$ Department of Laboratory Medicine, Gansu Provincial Hospital, Lanzhou, Gansu 730000, China \\ ${ }^{3}$ Graduate School, Chinese Academy of Medical Sciences and Peking Union Medical College, Dongdan, Beijing 100730, China \\ ${ }^{4}$ Department of Clinical Pharmacy, The People's Hospital of Lishui, Lishui 323000, China \\ ${ }^{5}$ Department of Clinical Pharmacy, Ningbo Medical Center Lihuili Eastern Hospital, Ningbo 315000, China \\ ${ }^{6}$ Department of Nephrology, Beijing Hospital, Ministry of Health, Beijing 100730, China \\ ${ }^{7}$ Department of Laboratory Medicine, Beijing Hospital of the Ministry of Health, Beijing 100730, China \\ ${ }^{8}$ Department of Pharmacology, Wenzhou Medical University, University Town, Wenzhou, Zhejiang 325035, China
}

Correspondence should be addressed to Jian-Ping Cai; caijp61@vip.sina.com

Received 15 May 2017; Revised 3 September 2017; Accepted 12 September 2017; Published 19 October 2017

Academic Editor: Aiqing Li

Copyright @ 2017 Wan-Xia Wang et al. This is an open access article distributed under the Creative Commons Attribution License, which permits unrestricted use, distribution, and reproduction in any medium, provided the original work is properly cited.

\begin{abstract}
To evaluate RNA oxidation in the early stage of diabetic nephropathy, we applied an accurate method based on isotope dilution highperformance liquid chromatography-triple quadruple mass spectrometry to analyze the oxidatively generated guanine nucleosides in renal tissue and urine from $\mathrm{db} / \mathrm{db}$ mice of different ages. We further investigated the relationship between these oxidative stress markers, microalbumin excretion, and histological changes. We found that the levels of 8-oxo-7,8-dihydroguanosine (8-oxoGuo) and 8-oxo-7,8-dihydro-2'-deoxyguanosine (8-oxodGuo) were increased in the urine and renal tissue of $\mathrm{db} / \mathrm{db}$ mice and $\mathrm{db} / \mathrm{db}$ mice with early symptoms of diabetic nephropathy suffered from more extensive oxidative damage than lean littermate control $\mathrm{db} / \mathrm{m}$ mice. Importantly, in contrast to the findings in $\mathrm{db} / \mathrm{m}$ mice, the 8-oxoGuo levels in the urine and renal tissue of $\mathrm{db} / \mathrm{db}$ mice were higher than those of 8-oxodGuo at four weeks. These results indicate that RNA oxidation is more apparent than DNA oxidation in the early stage of diabetic nephropathy. RNA oxidation may provide new insight into the pathogenesis of diabetic nephropathy, and urinary 8-oxoGuo may represent a novel, noninvasive, and easily detected biomarker of diabetic kidney diseases if further study could clarify its source and confirm these results in a large population study.
\end{abstract}

\section{Introduction}

Diabetic kidney disease (DKD) is the leading cause of kidney failure worldwide and the strongest predictor of mortality in patients with diabetes $[1,2]$. Oxidative stress caused by increased free radical production is believed to play a central role in the development of DKD [3]. Previous reports have indicated that DNA marker 8-oxo-7,8-dihydro-2'-deoxyguanosine (8-oxodGuo) oxidation is a useful clinical marker of diabetic nephropathy (DN) [4-7], but the conclusion is somewhat controversial [8].
In addition to DNA, RNA also undergoes significant oxidative damage. RNA oxidation is considered to be a marker of an early stage at which the clinical symptoms are very discrete in some diseases $[9,10]$ and may be useful for the prevention and therapy of these diseases. The RNA oxidation marker 8-oxo-7,8-dihydroguanosin (8-oxoGuo) was recently identified as an independent predictor of mortality in patients with established and treated type 2 diabetes [11]. Since DKD is the strongest predictor of mortality in patients with diabetes $[1,2]$, it is important to determine whether or not there is a relationship between RNA oxidation and diabetic nephropathy. 
Our previous study evaluating nucleic acid oxidation in type 2 diabetes and exploring its role in the development of this disease revealed increased DNA and RNA oxidation in type 2 diabetes, and type 2 diabetes patients with complications exhibited higher levels of 8-oxoGuo than those without complications [12]. We also found that oxidative damage to nucleic acids in the kidney of diabetic rats was more obvious than in other organs, especially RNA oxidation [13]. Although we have proposed that 8-oxoGuo may be correlated with diabetic nephropathy and that 8-oxoGuo in urine could be a useful and sensitive marker of diabetic nephropathy, there is little direct information about whether urinary oxidative stress markers correlate with damage in the tissue of diabetic nephropathy or early changes of diabetic nephropathy.

The $\mathrm{db} / \mathrm{db}$ mouse on the C57BLKS background has been investigated intensively and exhibits many features similar to human diabetic nephropathy. These mice are a good model for the early pathological changes of human DN $[14,15]$. To confirm whether or not RNA oxidation is an early pathogenesis in $\mathrm{DKD}$, we applied an accurate method based on isotope dilution high-performance liquid chromatographytriple quadruple mass spectrometry (ID-HPLC-MS/MS), a sensitive and reliable method, to evaluate oxidative guanine nucleosides in renal tissue and urine from $\mathrm{db} / \mathrm{db}$ mice of different ages. We further investigated the relationship between the urinary excretion of oxidative stress markers, microalbumin excretion, and histological changes. Our results suggest that urinary 8-oxoGuo could be a novel biomarker of diabetic kidney diseases.

\section{Materials and Methods}

2.1. Chemicals. The 8-oxodGuo (>98\% purity), 2deoxyguanosine (dGuo; $>98 \%$ purity), guanosine (Guo; 98\% purity), deferoxamine mesylate (DFOM), and HPLCgrade methanol were obtained from Sigma-Aldrich Inc., USA. 8-oxoGuo (>98\% purity) was obtained from Alexis Biochemicals (San Diego, CA, USA). HPLC-grade ammonium acetate was obtained from Fisher Scientific, USA. Heavy-isotope-labeled 8-oxo- $\left[{ }^{15} \mathrm{~N}_{5}\right] \mathrm{dGuo},\left[{ }^{15} \mathrm{~N}_{5}\right] \mathrm{dGuo}$, and $\left[{ }^{15} \mathrm{~N}_{5}\right]$ Guo were obtained from Cambridge Isotope Laboratories (Andover, MA, USA), and 8-oxo- $\left[{ }^{15} \mathrm{~N}_{2}{ }^{13} \mathrm{C}_{1}\right]$ Guo was obtained from Toronto Research Chemicals (Toronto, Canada). Water was deionized at 18.2 $\mathrm{M} \Omega$.

2.2. Experimental Animals. BKS.Cg-Dock $7^{\mathrm{m}}+/+$ Lepr $^{\mathrm{db}} / \mathrm{JNju}$ $(\mathrm{db} / \mathrm{db})$ mice were used as a model of type 2 diabetic nephropathy $[14,15]$, and their lean littermates $(\mathrm{db} / \mathrm{m})$ were used as controls. Male mice were purchased from Nanjing Biomedical Research Institute of Nanjing University and maintained under specific-pathogen-free conditions $\left(24 \pm 2^{\circ} \mathrm{C}, 12 \mathrm{~h}\right.$ light/dark cycle with light on at 7:00 AM) with free access to water and food. $\mathrm{Db} / \mathrm{db}$ mice and their lean littermates $(\mathrm{db} / \mathrm{m})$ were divided into four age groups (ages $4,8,12$, and 16 weeks), with each group including six mice. This study was performed with the approval of the local ethics committee, and all of the experiments were carried out according to the National Institutes of Health Guide for the Care and Use of Laboratory Animals.

2.3. Sample Collection. For the measurement of fasting blood glucose, blood was obtained from the tail vein after fasting animals for $12 \mathrm{~h}$ and analyzed with a portable blood glucose monitor (Bayer's BREEZE 2 blood glucose meter, Germany). Well-mixed $24 \mathrm{~h}$ urine was collected from mice in metabolic cages, and after it was centrifuged at $3000 \mathrm{~g}$ for $10 \mathrm{~min}$, supernatant was frozen at $-80^{\circ} \mathrm{C}$ until use. Blood was collected into a $\mathrm{Na}_{2}$ EDTA anticoagulantpretreated vacuum tube after mice had fasted for $16 \mathrm{~h}$ and was immediately centrifuged at $4^{\circ} \mathrm{C}, 3000 \mathrm{rpm}$ for $10 \mathrm{~min}$. Plasma samples were isolated and frozen at $-80^{\circ} \mathrm{C}$ before the analysis. After being dissected on ice, the kidneys were frozen in liquid nitrogen immediately and stored at $-80^{\circ} \mathrm{C}$ or placed in fixatives according to the experimental design.

2.4. Assessment of Renal Function and Microalbuminuria. A high-performance liquid chromatography with UV detector system (HPLC-UV) method developed by our laboratory [16] was used for creatinine quantitation in plasma and urine. Urinary microalbumin excretion was measured using a specific enzyme-linked immunosorbent assay (ELISA) for the quantitative determination of microalbumin in mouse urine (ab108792; Abcam, Cambridge, UK).

2.5. Histopathology. Kidneys were immersed in $10 \%$ formalin and embedded in paraffin. Sections ( $5 \mu \mathrm{m}$ thick) were processed for the histopathology study. The histopathology was investigated using hematoxylin and eosin (H\&E) and periodic acid-Schiff (PAS) staining. In addition, small pieces of renal cortex were fixed in $2 \%$ glutaraldehyde, postfixed in $1 \%$ osmium tetroxide, and embedded in Araldite M (SigmaAldrich). Ultra-thin sections were counterstained with uranyl acetate and lead citrate and examined using a transmission electron microscope. Electron micrographs were used to determine the glomerular basement membrane (GBM) thickness and podocyte foot process width $(\mathrm{FPw})$ as previously described $[17,18]$.

2.6. Preparation and Hydrolysis of Nucleic Acids from the Kidney. The preparation and hydrolysis of nucleic acids were performed according to our laboratory protocol with some modifications [16]. In brief, genomic DNA was prepared using the ESCODD recommended protocol [19]. Total RNA was extracted using the TRIzol (Invitrogen, CA, USA) reagent according to the manufacturer's instructions. DFOM was added to reduce the background levels of oxidized DNA and RNA.

For DNA hydrolysis, aliquots of samples containing $20 \mu \mathrm{g}$ of nucleic acids were subjected to denaturation by heating at $95^{\circ} \mathrm{C}$ for $3 \mathrm{~min}$ and chilling rapidly. The denatured DNA was then incubated with nuclease P1 (Wako Pure Chemical, Osaka, Japan) in $0.3 \mathrm{M}$ sodium acetate- $1 \mathrm{mM}$ $\mathrm{ZnSO} 4, \mathrm{pH} 5.3$, and incubated at $37^{\circ} \mathrm{C}$ for $2 \mathrm{~h}$. Five units of alkaline phosphatase (New England Biolabs, USA) was then added, and the mixture was incubated for $1 \mathrm{~h}$ at $37^{\circ} \mathrm{C}$. To $90 \mu \mathrm{l}$ of the DNA hydrolysate solution, $5 \mu \mathrm{l}$ of $100 \mathrm{ng} / \mathrm{ml}$ 
TABLE 1: Biochemical and physical characteristics of experimental groups.

\begin{tabular}{|c|c|c|c|c|c|c|c|c|}
\hline Characteristic & $\mathrm{db} / \mathrm{m}-4 \mathrm{w}$ & $\mathrm{db} / \mathrm{db}-4 \mathrm{w}$ & $\mathrm{db} / \mathrm{m}-8 \mathrm{w}$ & $\mathrm{db} / \mathrm{db}-8 \mathrm{w}$ & $\mathrm{db} / \mathrm{m}-12 \mathrm{w}$ & $\mathrm{db} / \mathrm{db}-12 \mathrm{w}$ & $\mathrm{db} / \mathrm{m}-16 \mathrm{w}$ & $\mathrm{db} / \mathrm{db}-16 \mathrm{w}$ \\
\hline Body weight (g) & $15.5 \pm 1.4$ & $23.8 \pm 0.8$ & $23.8 \pm 1.4$ & $45.7 \pm 2.1$ & $26.7 \pm 1.3$ & $48.9 \pm 5.0$ & $28.9 \pm 2.6$ & $44.5 \pm 3.5$ \\
\hline Kidney weight (mg) & $142.3 \pm 8.8$ & $173.6 \pm 29.7$ & $176.2 \pm 17.9$ & $238.7 \pm 67.6$ & $174.3 \pm 13.4$ & $234 \pm 26.4$ & $186.8 \pm 25.7$ & $222.7 \pm 40.6$ \\
\hline $\begin{array}{l}\text { Kidney wt/body } \\
w t, \times 10^{-3}\end{array}$ & $8.0 \pm 0.5$ & $5.3 \pm 1.0$ & $7.8 \pm 0.7$ & $5.2 \pm 1.3$ & $7.5 \pm 0.5$ & $4.9 \pm 0.6$ & $7.6 \pm 0.8$ & $5.5 \pm 1.1$ \\
\hline $\begin{array}{l}\text { Blood glucose } \\
(\mathrm{mmol} / \mathrm{L})\end{array}$ & $7.9 \pm 0.5$ & $13.4 \pm 3.9$ & $8.1 \pm 0.8$ & $24.1 \pm 5.5$ & $6.8 \pm 0.6$ & $29.7 \pm 2.9$ & $6.8 \pm 0.3$ & $34.7 \pm 3.2$ \\
\hline $\begin{array}{l}\text { Plasma creatinine } \\
(\mathrm{mg} / \mathrm{dL})\end{array}$ & $0.094 \pm 0.007$ & $0.083 \pm 0.01$ & $0.088 \pm 0.01$ & $0.089 \pm 0.01$ & $0.093 \pm 0.005$ & $0.103 \pm 0.02$ & $0.096 \pm 0.008$ & $0.106 \pm 0.01$ \\
\hline
\end{tabular}

8-oxo- $\left[{ }^{15} \mathrm{~N}_{5}\right] \mathrm{dGuo}$, and $5 \mu \mathrm{l}$ of $10 \mu \mathrm{g} / \mathrm{ml}\left[{ }^{15} \mathrm{~N}_{5}\right] \mathrm{dGuo}$ were added. The samples were then gently mixed and centrifuged at $12,000 \mathrm{~g}$ for $5 \mathrm{~min}$ at $4^{\circ} \mathrm{C}$, and aliquots of the supernatant were taken for the HPLC-MS/MS analysis.

For RNA hydrolysis, $20 \mu \mathrm{g}$ of RNA in $80 \mu \mathrm{l}$ of $1 \mathrm{mM}$ DFOM was incubated with 5 units of nuclease P1 at $37^{\circ} \mathrm{C}$ for $2 \mathrm{~h}$, followed by an additional incubation with 5 units of alkaline phosphatase at $37^{\circ} \mathrm{C}$ for $1 \mathrm{~h}$. Then, $5 \mu \mathrm{l}$ of $100 \mathrm{ng} / \mathrm{ml}$ 8-oxo- $\left[{ }^{15} \mathrm{~N}_{2}{ }^{13} \mathrm{C}_{1}\right]$ Guo and $5 \mu \mathrm{l}$ of $5 \mu \mathrm{g} / \mathrm{ml}\left[{ }^{15} \mathrm{~N}_{5}\right]$ Guo were added to $90 \mu \mathrm{l}$ of the RNA hydrolysates. These samples were also gently mixed and centrifuged at $12,000 \mathrm{~g}$ for $5 \mathrm{~min}$ at $4^{\circ} \mathrm{C}$, and aliquots of the supernatant were taken for the HPLC-MS/MS analysis.

2.7. Preparation of Urine Samples for the Oxidatively Generated Guanine Nucleoside Analysis. Frozen urine was thawed at $37^{\circ} \mathrm{C}$ for $5 \mathrm{~min}$ and centrifuged at $12,000 \mathrm{~g}$ for $5 \mathrm{~min}$ at $4^{\circ} \mathrm{C}$. For the oxidatively generated guanine nucleoside analysis, $100 \mu \mathrm{l}$ of urine was mixed with $400 \mu \mathrm{l}$ of $70 \%$ methanol solution to obtain a 1:5 diluted urine sample. Then, $10 \mu \mathrm{l}$ of $100 \mathrm{pg} / \mu \mathrm{l}\left[{ }^{15} \mathrm{~N}_{5}\right] 8$-oxodGuo and $10 \mu \mathrm{l}$ of $100 \mathrm{pg} / \mu \mathrm{l}\left[{ }^{15} \mathrm{~N}_{2}{ }^{13} \mathrm{C}_{1}\right] 8$-oxoGuo were added to the urine sample and centrifuged at $12,000 \mathrm{~g}$ for $15 \mathrm{~min}$ at $4^{\circ} \mathrm{C}$. Finally, $100 \mu \mathrm{l}$ of the supernatant was collected for the HPLC-MS/MS analysis of 8-oxodGuo and 8-oxoGuo.

2.8. Chromatographic and Mass Spectrometric Analysis. An Agilent 1290 Infinity UHPLC system was used to directly inject $4 \mu \mathrm{l}$ samples onto an Agilent Zorbax SB-Aq $(1.8 \mu \mathrm{m}$, $3.0 \times 100 \mathrm{~mm}$ ) column that was maintained at a column temperature of $50^{\circ} \mathrm{C}$. Sample separations were achieved using a $300 \mu \mathrm{l} / \mathrm{min}$ flow rate with the mobile phase consisting of $10 \mathrm{mM}$ ammonium acetate at $\mathrm{pH} 3.75$ (A) and 100\% methanol (B). The sample room temperature was kept at $4^{\circ} \mathrm{C}$. Early- and late-eluting components were discarded to reduce the contamination of the ion source.

An Agilent 6490 QQQ LC/MS system with a highflow iFunnel technology ionization source controlled by Agilent MassHunter Workstation software program (version B.04.01; Agilent) was used for all HPLC-MS/MS sample analyses. All acquisition methods used the following parameters: $3500 \mathrm{~V}$ capillary voltage and $1500 \mathrm{~V}$ nozzle voltage, a sheath gas flow of $11 \mathrm{~L} / \mathrm{min}$ (UHP nitrogen) at a temperature of $400^{\circ} \mathrm{C}$, a drying gas flow of $14 \mathrm{~L} / \mathrm{min}$ at a temperature of $200^{\circ} \mathrm{C}$, and nebulizer gas flow at 20 psi. Quantification was performed using a multiple reaction monitoring model with a dwell time of $100 \mathrm{~ms}$ per transition for all compounds. All of the optimized values are summarized in Supplementary Table $1 \mathrm{~s}$ to $3 \mathrm{~s}$ available online at https://doi.org/10.1155/ 2017/2353729. The data processing was carried out using the MassHunter Workstation software program for Quantitative Analysis (version B.06.00; Agilent).

2.9. Statistical Analysis. All values are presented as the mean \pm standard deviation (SD). Statistical significance was determined by a one-way analysis of variance (ANOVA), and levels of 8-oxoGuo or 8-oxodGuo between groups were compared by an ANOVA with the post hoc least significance difference test. A Pearson's correlation analysis was performed to examine the relationships between nucleotide acid oxidation markers and urinary microalbumin. Multiple linear regression analysis was further used to determine the relationships between nucleotide acid oxidation markers and urinary microalbumin. Statistical analysis was performed using the SPSS 22.0 software program (IBM Corporation, New York, NY, USA), and graphs were plotted using the GraphPad Prism 5.0 software program (GraphPad Software Inc., La Jolla, CA, USA). A two-sided $P$ value $<0.05$ was deemed statistically significant.

\section{Result}

3.1. Physical and Biochemical Characteristics of the Study Subjects. The body weight, kidney weight, and blood glucose were significantly higher for the $\mathrm{db} / \mathrm{db}$ mice than for the $\mathrm{db} / \mathrm{m}$ mice (Table 1). Total kidney-to-body weight ratios were lower in all $\mathrm{db} / \mathrm{db}$ mice than in $\mathrm{db} / \mathrm{m}$ mice. Although the difference in plasma creatinine was not statistically significant between the experimental groups, increased microalbuminuria (Figure 1) was shown in some groups of $\mathrm{db} / \mathrm{db}$ mice (8- to 16-week-old mice) compared to the same-age $\mathrm{db} / \mathrm{m}$ mice. Renal histology in these groups of $\mathrm{db} / \mathrm{db}$ mice (8- to 16-week-old mice) was characterized by mesangial extracellular matrix expansion (Figure 2(a)). The glomerular ultrastructure was examined by transmission electron microscopy (Figure 2(b)). Compared with the control mice, there was segmental thickening of the GBM in $\mathrm{db} / \mathrm{db}$ mice (8- to 16-weekold mice) with no electron-dense deposits (Figures 2(b) and 2(c)). In addition, podocyte effacement or loss and mesangial 


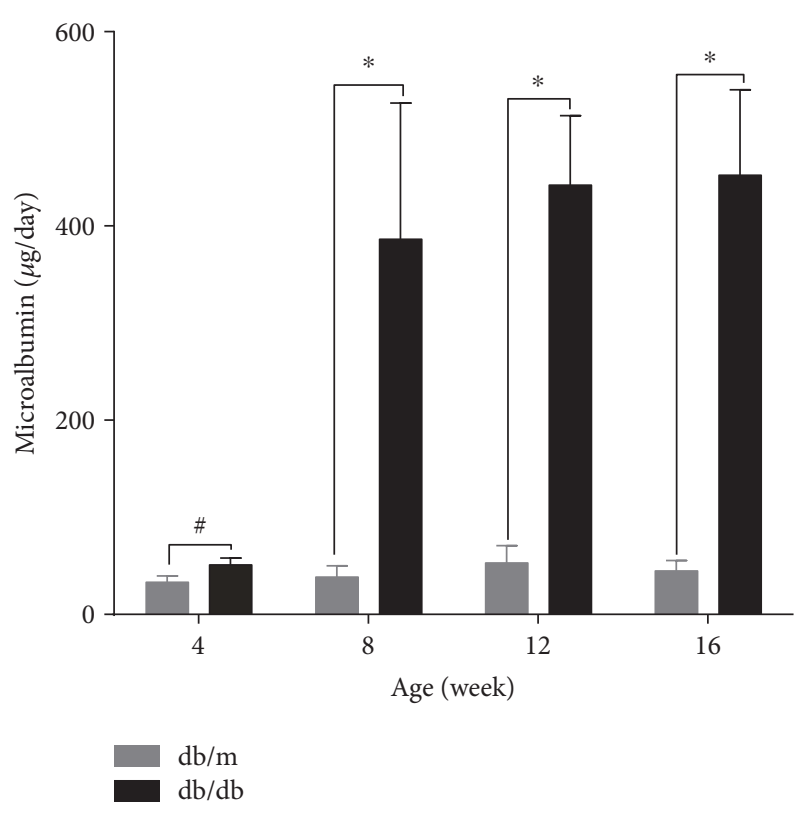

FIGURE 1: Increased albuminuria in $\mathrm{db} / \mathrm{db}$ mice. $\mathrm{db} / \mathrm{db}$ represents BKS.Cg-Dock $7^{\mathrm{m}}+/+$ Lepr $^{\mathrm{db}} / \mathrm{JNju}$ mice and $\mathrm{db} / \mathrm{m}$ represents their lean littermates. Samples from 4-, 8-, 12-, and 16-week-old mice were examined. From 8 to 16 weeks of age, db/db mice showed increased microalbuminuria compared with their lean $\mathrm{db} / \mathrm{m}$ littermates. The data are shown as the means $\pm \mathrm{SD}$. (white-colored bars) $\mathrm{db} / \mathrm{m}$. (black-colored bars) $\mathrm{db} / \mathrm{db},{ }^{*} P<0.05$ versus respective control, ${ }^{\#} P>0.05$ compared with the control.

extracellular matrix expansion were more apparent in $\mathrm{db} / \mathrm{db}$ mice (4- to 16-week-old mice) than in the same-age $\mathrm{db} / \mathrm{m}$ mice (Figures 2(b) and 2(d)). Taken together, these findings show that the renal changes in $\mathrm{db} / \mathrm{db}$ mice were consistent with early diabetic nephropathy.

3.2. Quantitation of Oxidized Guanine Nucleosides from DNA or RNA of the Kidney. We adopted the ESCODDrecommended protocol and further applied deferoxamine methylate to reduce the background level of oxidation. DNA was hydrolyzed to nucleosides by successive treatments with nuclease $\mathrm{P} 1$ and alkaline phosphatase. To each sample, $\left[{ }^{15} \mathrm{~N}_{5}\right]$ dGuo and 8-oxo- $\left[{ }^{15} \mathrm{~N}_{5}\right]$ dGuo were added to provide appropriate internal standards. The mixtures were subsequently applied to the HPLC-MS/MS system for the quantification of the two types of deoxyguanosine: dGuo and 8-oxodGuo. As shown in Figure 3(a), dGuo and 8-oxodGuo eluted at different distinct positions and were able to be assayed without cross-contamination.

The genomic DNA was prepared from the kidneys obtained from the mice at different stages of growth, and their 8-oxodGuo content was determined. The values were expressed as numbers of 8 -oxodGuo per $10^{6}$ residues of dGuo. To avoid the influence of age on the level of DNA oxidation, we compared the levels of 8-oxodGuo in $\mathrm{db} / \mathrm{db}$ mice and their lean $\mathrm{db} / \mathrm{m}$ littermates. These results are presented in Figure 3(b). The 8-oxodGuo content increased slightly with age, and the maximum values were observed at 16 weeks after birth, at which point the examination was terminated.
This age-dependent increase in the 8-oxodGuo content was found in both types of mice. The rates of increase were insignificant in $\mathrm{db} / \mathrm{db}$ mice compared with those in $\mathrm{db} / \mathrm{m}$ mice.

The amounts of 8-oxoGuo were determined in RNA derived from kidneys of the two types of mice. Precautions were again taken to minimize the levels of oxidation of the materials during the preparation of RNA as well as the enzymatic digestion to nucleosides. Under the conditions used for liquid chromatography, Guo and 8-oxoGuo were eluted at distinct positions (Figure $3(\mathrm{c})$ ). To ensure the accurate determination of these nucleosides, ${ }^{15} \mathrm{~N}$-substituted compounds were included as internal standards. Figure 3(d) shows the 8-oxoGuo contents of RNA derived from the kidneys of the two types of mice, and the values were analogously expressed as the numbers of 8-oxoGuo per $10^{6}$ residues of Guo. There were age-dependent increases in the 8-oxoGuo content in both the $\mathrm{db} / \mathrm{db}$ and the $\mathrm{db} / \mathrm{m}$ mice. However, the $\mathrm{db} / \mathrm{db}$ mice showed higher levels of 8-oxoGuo than their lean $\mathrm{db} / \mathrm{m}$ littermates, and the differences in the levels of 8-oxoGuo $/ 10^{6}$ Guo in RNA between $\mathrm{db} / \mathrm{db}$ and $\mathrm{db} / \mathrm{m}$ mice were more apparent than those observed with 8-oxodGuo/10 $10^{6}$ Guo in DNA.

3.3. Quantification of Oxidized Guanine Nucleosides in Urine. The urine samples were analyzed by HPLC-MS/MS. $\left[{ }^{15} \mathrm{~N}_{5}\right]$ 8-oxodGuo and $\left[{ }^{15} \mathrm{~N}_{2}{ }^{13} \mathrm{C}_{1}\right]$ 8-oxoGuo were used as internal standards, and the values were expressed as the total volume per day. The results are shown in Figure 4. The amounts of 8-oxodGuo and 8-oxoGuo increased with age in both types of mice, and significant differences were observed between the $\mathrm{db} / \mathrm{db}$ and their lean $\mathrm{db} / \mathrm{m}$ littermates. The levels of 8-oxodGuo, as well as 8-oxoGuo, were much higher in the urine of $\mathrm{db} / \mathrm{db}$ mice than in age-matched control $\mathrm{db} / \mathrm{m}$ mice. Furthermore, in the urine, the level of 8-oxoGuo was significantly higher than that of 8-oxodGuo.

3.4. Correlations of 8-oxodGuo/8-oxoGuo between Urine and Tissue. Because urinary 8-oxodGuo or 8-oxoGuo are known as general oxidative markers, we analyzed the correlation of these markers between renal tissue and urine. As shown in Figure 5, urinary 8-oxodGuo and 8-oxoGuo were associated with their respective levels in the kidney, except for 8oxodGuo in $\mathrm{db} / \mathrm{m}$ mice (urinary 8-oxodGuo/day versus renal 8-oxodGuo $/ 10^{6} \mathrm{dGuo}$ in $\mathrm{db} / \mathrm{m}$ mice, $r=0.396, P=$ 0.084 ; urinary 8-oxodGuo/day versus renal 8-oxodGuo/ $10^{6} \mathrm{dGuo}$ in $\mathrm{db} / \mathrm{db}$ mice, $r=0.568, P<0.01$; urinary 8 oxoGuo/day versus renal 8 -oxoGuo $/ 10^{6} \mathrm{Guo}$ in $\mathrm{db} / \mathrm{m}$ mice, $r=0.542, \quad P<0.05$; urinary 8 -oxoGuo/day versus renal 8 -oxoGuo $/ 10^{6} \mathrm{Guo}$ in $\mathrm{db} / \mathrm{db}$ mice $r=0.661, P<0.01$ ).

3.5. Correlations between 8-oxodGuo/ 8-oxoGuo and Urinary Micro-albumin. Figure 6 shows the relationship between the levels of 8-oxodGuo or 8-oxoGuo and urinary microalbumin. 8-oxodGuo and 8-oxoGuo levels in kidney closely paralleled the increase in microalbumin levels in urine (renal 8-oxodGuo $/ 10^{6} \mathrm{dGuo}$ versus urinary micro-albumin/ day in $\mathrm{db} / \mathrm{m}$ mice, $r=0.495, P<0.05$; renal 8 -oxodGuo/ $10^{6} \mathrm{dGuo}$ and urinary microalbumin/day in $\mathrm{db} / \mathrm{db}$ mice, $r=0.576, P<0.01$; renal 8 -oxoGuo $/ 10^{6}$ Guo versus urinary microalbumin/day in $\mathrm{db} / \mathrm{m}$ mice, $r=0.510, P<0.05$; renal 

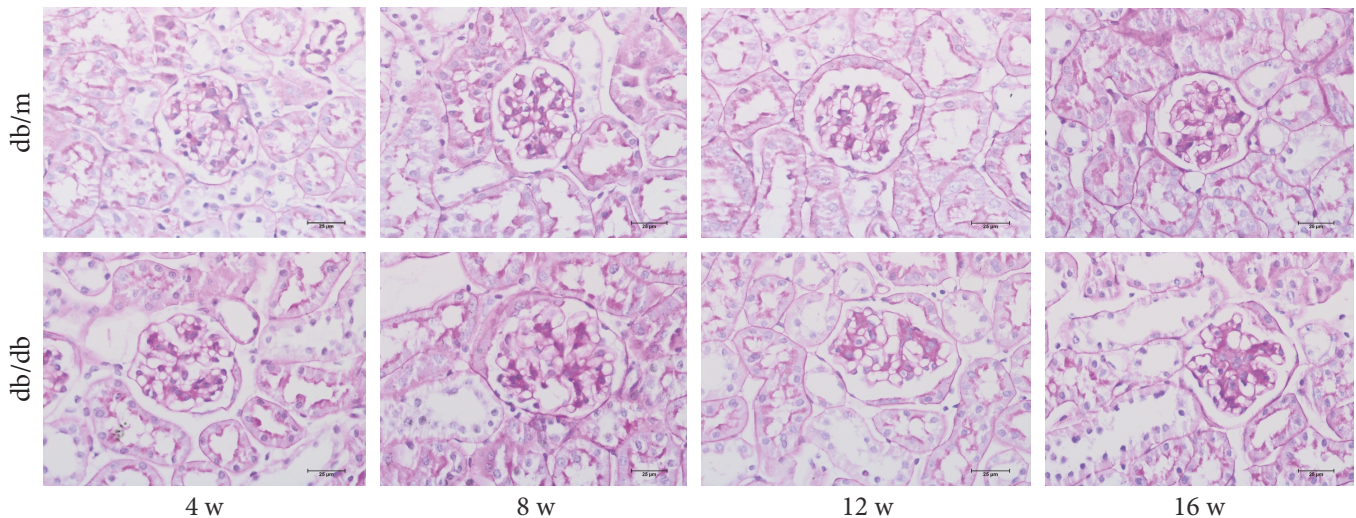

(a)
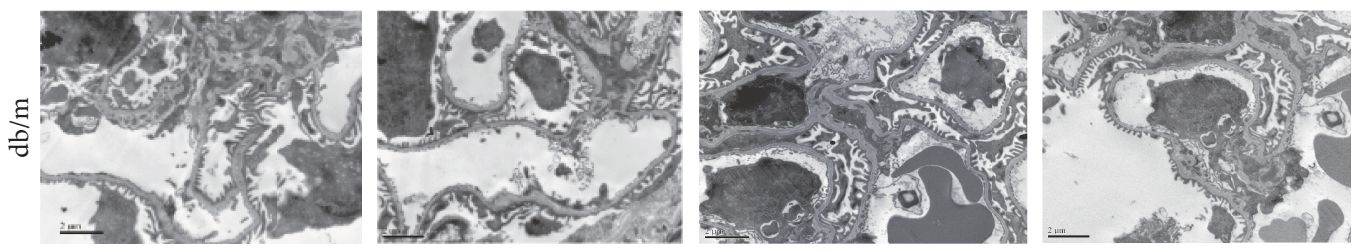

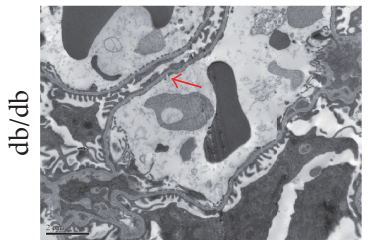

$4 \mathrm{w}$

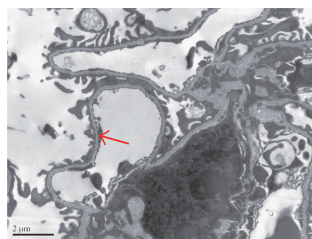

$8 \mathrm{w}$

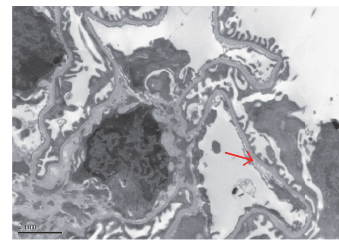

$12 \mathrm{w}$

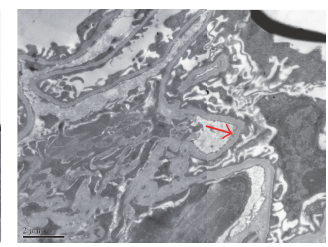

$16 \mathrm{w}$

(b)

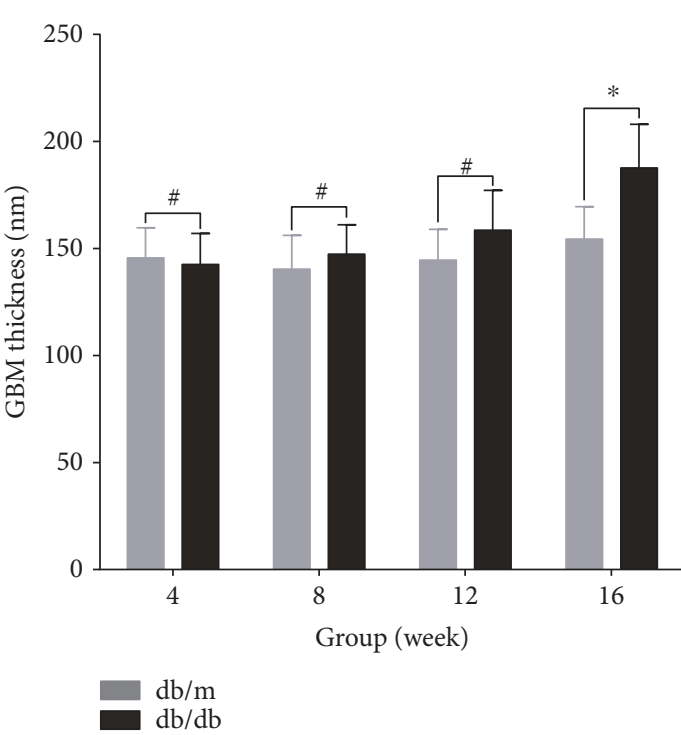

(c)

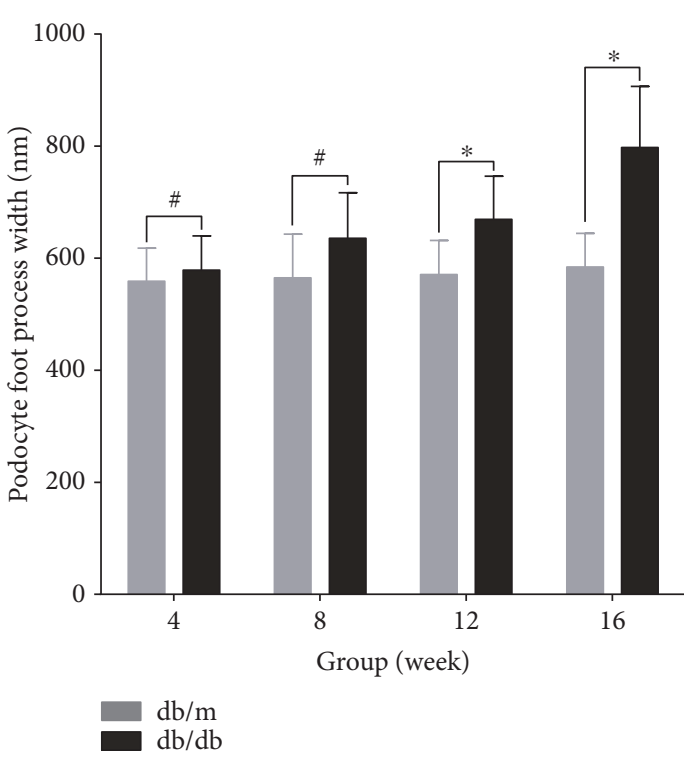

(d)

FiguRE 2: Histological and ultra-structural characteristics in diabetic $\mathrm{db} / \mathrm{db}$ mice. $\mathrm{db} / \mathrm{db}$ represents BKS.Cg-Dock $7^{\mathrm{m}}+/+\mathrm{Lepr}{ }^{\mathrm{db}} / \mathrm{JNju}$ mice, and $\mathrm{db} / \mathrm{m}$ represents their lean littermates. Samples from 4-, 8-, 12-, and 16-week-old mice were examined, and the results are shown as $4 \mathrm{w}, 8 \mathrm{w}, 12 \mathrm{w}$, and $16 \mathrm{w}$, respectively. (a) Periodic acid-Schiff stain (original magnification, $\times 400$ ) indicated a normal appearance in the outer cortex of control db/m mice and an increase in the mesangial matrix and glomerular hypertrophy in diabetic $\mathrm{db} / \mathrm{db}$ mice. Scale bar: $25 \mu \mathrm{m}$. (b) An electron-microscopic image (original magnification, 8000x) shows a normal appearance of the glomerulus in $\mathrm{db} / \mathrm{m}$ mice and podocyte effacement or loss and mesangial extracellular matrix expansion and irregular glomerular basement membrane (GBM) thickness (red arrow) in $\mathrm{db} / \mathrm{db}$ mice. Scale bar: $2 \mu \mathrm{m}$. (c) GBM thickness (nanometers). (d) Podocyte foot process width (FPw) (nanometer). The GBM and FPw are shown as the means \pm SD. (white-colored bars) $\mathrm{db} / \mathrm{m}$. (black-colored bars) $\mathrm{db} / \mathrm{db},{ }^{*} P<0.05 \mathrm{versus}$ respective control, ${ }^{\#} P>0.05$ compared with the respective controls. 

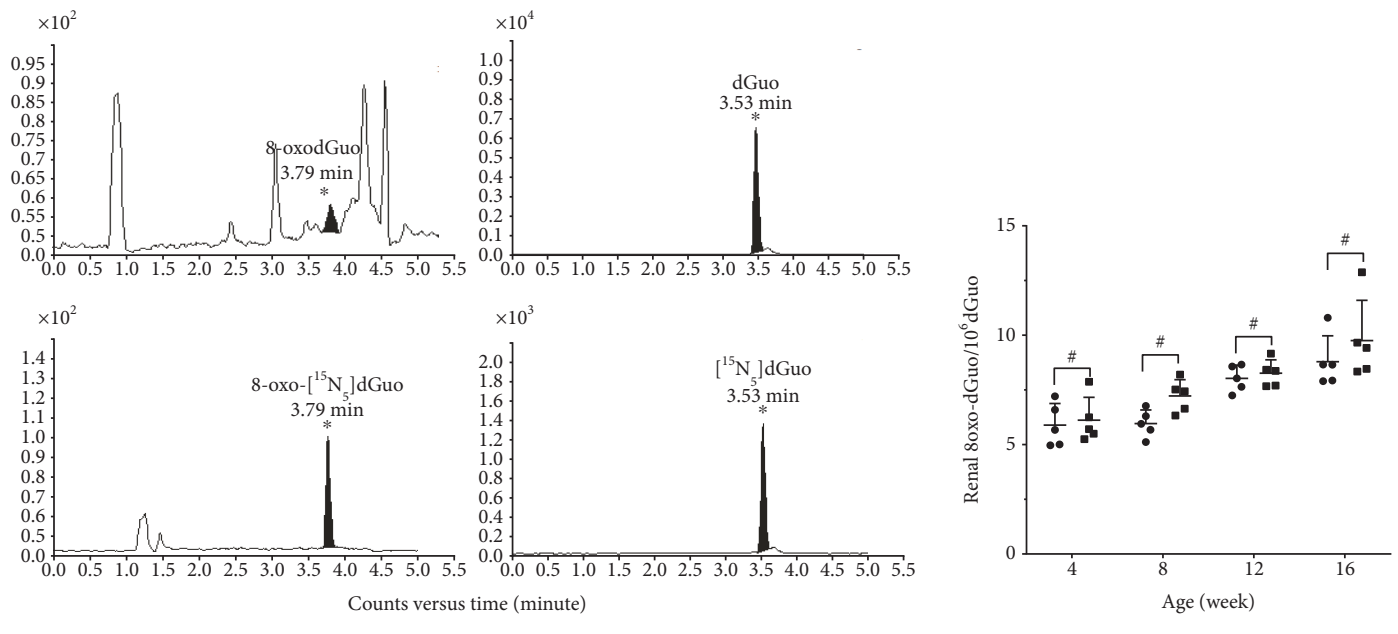

$-\mathrm{db} / \mathrm{m}$
- $\mathrm{db} / \mathrm{db}$

(a)

(b)
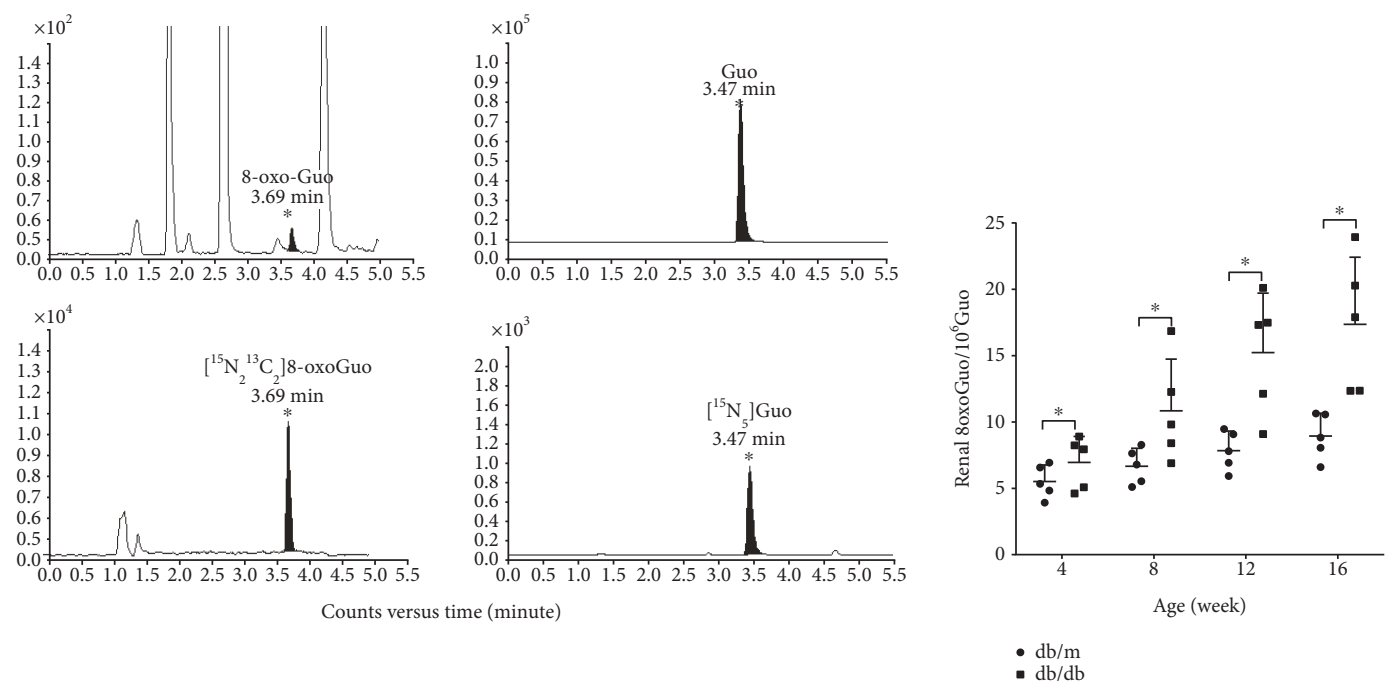

(c)

(d)

Figure 3: The HPLC-MS/MS determination of the concentrations of 8-oxodGuo and 8-oxoGuo in the kidneys of $\mathrm{db} / \mathrm{db}$ mice. $\mathrm{db} / \mathrm{db}$ represents BKS.Cg-Dock $7^{\mathrm{m}}+/+\mathrm{Lepr}^{\mathrm{db}} / \mathrm{JNju}$ mice, and db/m represents their lean littermates. Samples from 4-, 8-, 12-, and 16-week-old mice were examined. (a) HPLC-MS/MS chromatograms of 8-oxodGuo, dGuo, 8-oxo- $\left[{ }^{15} \mathrm{~N}_{5}\right] \mathrm{dGuo}$, and $\left[{ }^{15} \mathrm{~N}_{5}\right] \mathrm{dGuo}$. (b) Increases in the level of 8-oxodGuo/10 $\mathrm{dGuo}$ in the kidneys of $\mathrm{db} / \mathrm{db}$ and $\mathrm{db} / \mathrm{m}$ mice ( $n=5$ per group). (c) HPLC-MS/MS chromatograms of 8-oxoGuo, Guo, 8-oxo- $\left[{ }^{15} \mathrm{~N}_{2}{ }^{13} \mathrm{C}_{1}\right]$ Guo, and $\left[{ }^{15} \mathrm{~N}_{5}\right]$ Guo. (d) Increases in the level of 8-oxoGuo/10 6 Guo in the kidneys of $\mathrm{db} / \mathrm{db}$ and $\mathrm{db} / \mathrm{m} \mathrm{mice}(n=5$ per group). The data are shown as the means $\pm \mathrm{SD}$. (black-colored dots) $\mathrm{db} / \mathrm{m}$. (black-colored squares) $\mathrm{db} / \mathrm{db},{ }^{*} P<0.05 \mathrm{versus}$ the respective controls. ${ }^{*} P>0.05$ compared with the respective controls.

8-oxoGuo $/ 10^{6}$ Guo versus urinary microalbumin/day in $\mathrm{db} / \mathrm{db}$ mice, $r=0.601, P<0.01)$. There were also significant correlations between 8-oxodGuo or 8-oxoGuo and microalbumin in urine (8-oxodGuo versus microalbumin per day in urine from $\mathrm{db} / \mathrm{m}$ mice, $r=0.442, P<0.05 ; 8$-oxodGuo versus microalbumin per day in urine from $\mathrm{db} / \mathrm{db}$ mice, $r=0.506, P<0.05 ; 8$-oxoGuo versus microalbumin per day in urine from $\mathrm{db} / \mathrm{m}$ mice, $r=0.437, P<0.05 ; 8$-oxoGuo versus microalbumin per day in urine from $\mathrm{db} / \mathrm{db}$ mice, $r=0.701, P<0.01)$. Multiple linear regression analysis of microalbumin and nucleotide acid oxidation markers identified urinary 8-oxoGuo as the predominant indicator of the severity of microalbuminuria (Supplementary Table 4s).

\section{Discussion}

DNA and RNA oxidations have been linked to diseases such as cancer, arteriosclerosis, neurodegeneration, and diabetes. The measurement of urinary 8-oxodGuo and 8-oxoGuo has accordingly gained increasing interest, probably because such measurement constitutes a noninvasive method that can be used in vivo in humans as well as animals. A previous study provided evidence that 8-oxodGuo in urine is a useful clinical marker for predicting the development of diabetic nephropathy in diabetic patients [6]. However, another study recently found that, compared with UACR, urinary 8OHdGuo is not a useful clinical marker for predicting such 


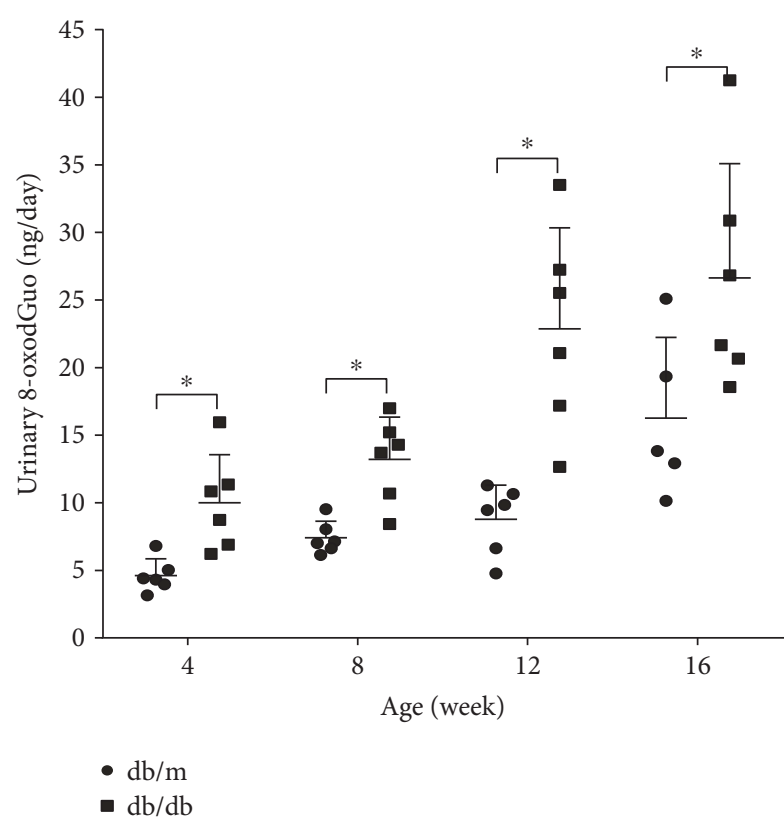

(a)

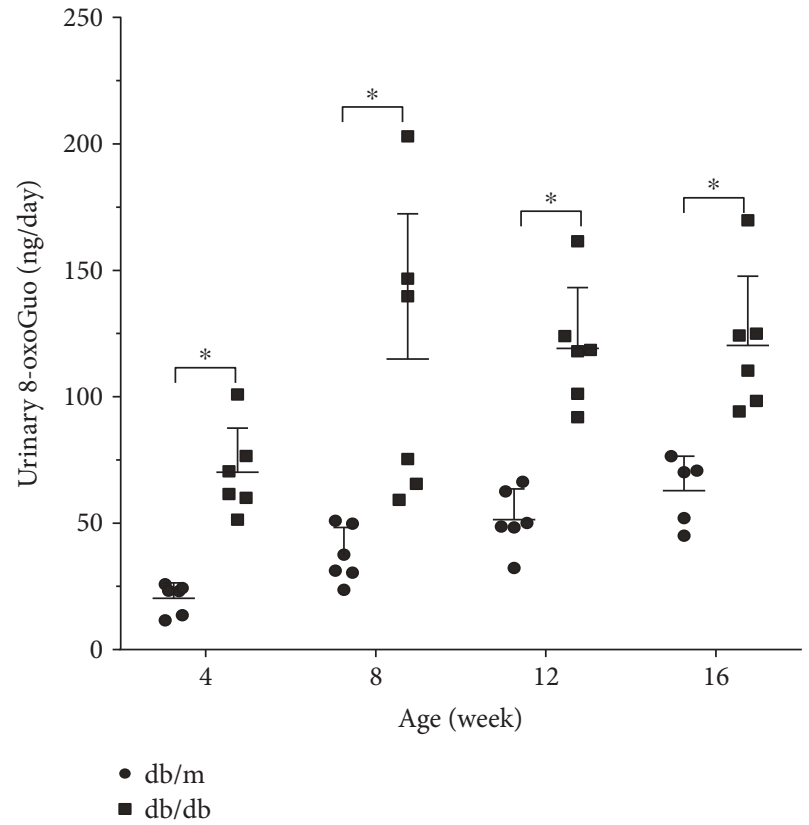

(b)

Figure 4: The HPLC-MS/MS determination of the concentrations of 8-oxodGuo and 8-oxoGuo in the urine of db/db mice. $\mathrm{db} / \mathrm{db}$ represents BKS.Cg-Dock $7^{\mathrm{m}}+/+\mathrm{Lepr}^{\mathrm{db}} / \mathrm{JNju}$ mice, and $\mathrm{db} / \mathrm{m}$ represents their lean littermates. Samples from 4-, 8-, 12-, and 16-week-old mice were examined. (a) Increases in the level of 8 -oxodGuo/day in the urine of $\mathrm{db} / \mathrm{db}$ and $\mathrm{db} / \mathrm{m}$ mice ( $n=5$ or 6 per group). (b) Increases in the level of 8-oxoGuo/day in the urine of $\mathrm{db} / \mathrm{db}$ and $\mathrm{db} / \mathrm{m}$ mice $(n=5$ or 6 per group). The data are shown as the means \pm SD. (black-colored dots) $\mathrm{db} / \mathrm{m}$. (black-colored squares) $\mathrm{db} / \mathrm{db},{ }^{*} P<0.05$ versus the respective controls.

an outcome [8]. Given these conflicting findings, we believe that readers should pay attention to the following points: First, the nomenclature used is not consistent across authors, and the abbreviations for the same chemical entity differ over time and among authors, which may confuse readers and cause them to draw a different conclusion. Second, various methods have been used to determine the levels of 8-oxodGuo, and historically, the quantitation of urinary 8oxodGuo in diabetic nephropathy research has mainly been based on HPLC with electrochemical detection (HPLCECD) or ELISA [5, 6, 20-22], methods that are hampered by insufficient specificity and sensitivity [23].

Given that 2-deoxyguanosine (DNA) is oxidized to form 8 -oxodGuo while guanosine (RNA) is oxidized to form 8-oxoGuo, this study use 8-oxodGuo and 8-oxoGuo for the oxidized guanine nucleosides from DNA and RNA, respectively. We used a procedure based on HPLC-MS/MS, a gold-standard technique meeting the European Communities requirement, to determine the oxidative damage to DNA and RNA in renal tissue and urine samples more accurately. Although we used $\mathrm{db} / \mathrm{db}$ mice of different ages to investigate changes in the oxidative guanine nucleosides aggravation of renal injury in the early stage of diabetic nephropathy, we compared the levels of oxidative guanine nucleosides in $\mathrm{db} / \mathrm{db}$ mice and their lean $\mathrm{db} / \mathrm{m}$ littermates to avoid any influence of age on the level of nucleoside oxidation.

Of note, the $\mathrm{db} / \mathrm{db}$ mice showed higher levels of renal 8-oxodGuo and 8-oxoGuo than their lean $\mathrm{db} / \mathrm{m}$ littermates. However, a detailed statistical analysis of $\mathrm{db} / \mathrm{db}$ mice and their lean $\mathrm{db} / \mathrm{m}$ littermates showed that only the rates of increased renal 8-oxoGuo were significant in $\mathrm{db} / \mathrm{db}$ mice to $\mathrm{db} / \mathrm{m}$ mice. $\mathrm{Db} / \mathrm{db}$ mice showed higher levels of renal 8-oxoGuo than their lean $\mathrm{db} / \mathrm{m}$ littermates. These results not only indicate that $\mathrm{db} / \mathrm{db}$ mice with early symptoms of diabetic nephropathy suffered from more extensive oxidative nucleoside damage than their lean littermate control mice but also confirm our findings that RNA oxidation appeared earlier and was more apparent than DNA oxidation in diabetic nephropathy [13]. Though increased RNA oxidation in renal tissue is difficult and cannot alone be used to predictive for development diabetic nephropathy in vivo [24], it may provide an important hint that RNA oxidation is involved in the development of diabetic nephropathy.

The quantification of oxidized guanine nucleosides in urine also revealed markedly higher levels of 8-oxodGuo, as well as 8-oxoGuo, in the urine of $\mathrm{db} / \mathrm{db}$ mice compared with age-matched control $\mathrm{db} / \mathrm{m}$ mice, and the level of 8-oxoGuo was significantly higher than that of 8-oxodGuo. However, the urinary excretion of 8-oxodGuo and 8-oxoGuo is thought to indicate global oxidative stress to DNA or RNA and is recognized as a general marker of DNA and RNA oxidation [25-27]. Therefore, it is important to determine whether or not urinary 8-oxodGuo and 8-oxoGuo are associated with the same oxidative damage in renal tissue of diabetic nephropathy. Interestingly, our examination of the relationship of 8-oxodGuo and 8-oxoGuo between urine and renal tissue showed that the amount of 8-oxodGuo and 8 -oxoGuo in urine was in good agreement with the levels of renal 8-oxodGuo $/ 10^{6} \mathrm{dGuo}$ and 8 -oxoGuo $/ 10^{6} \mathrm{Guo}$, 


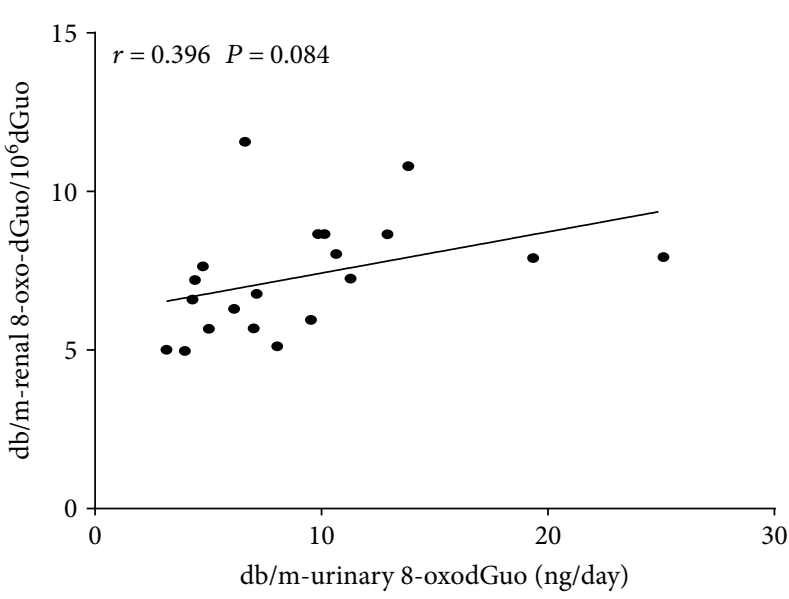

(a)

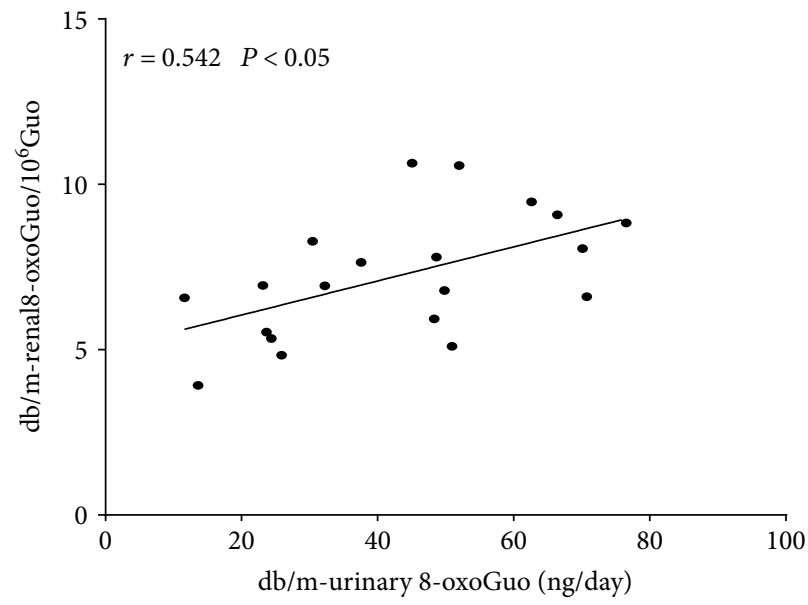

(c)

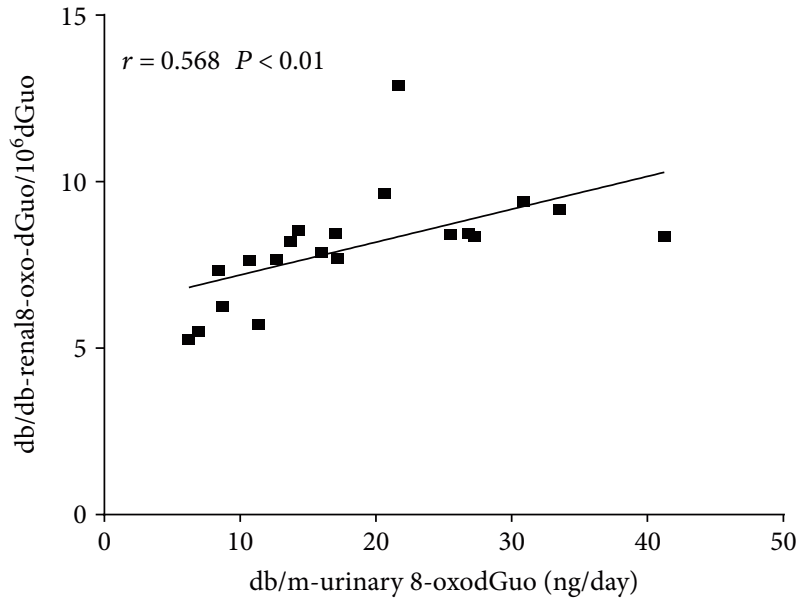

(b)

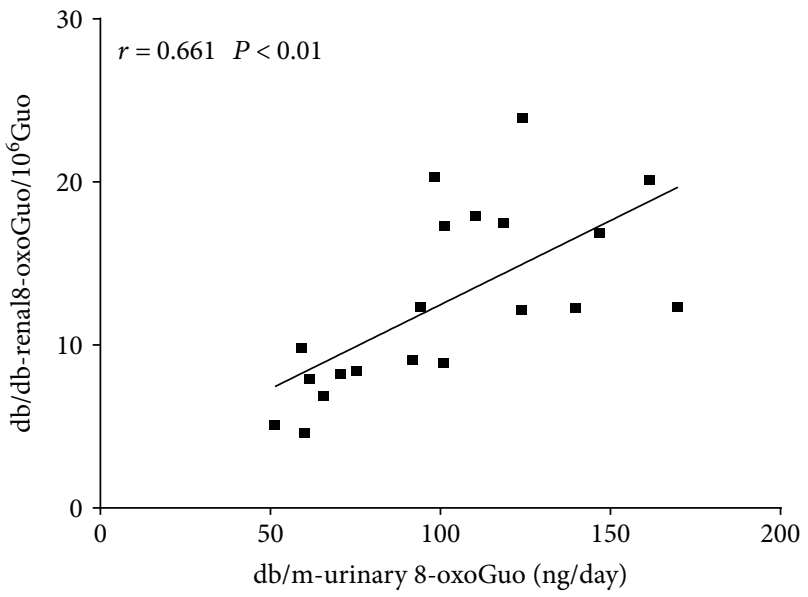

(d)

FIGURE 5: Correlations between urinary 8-oxodGuo/8-oxoGuo and renal 8-oxodGuo/8-oxoGuo. (a) Correlation between urinary 8-oxodGuo/ day and renal 8-oxodGuo $/ 10^{6} \mathrm{dGuo} \mathrm{in} \mathrm{db} / \mathrm{m}$ mice $(r=0.396, P=0.084)$. (b) Correlation between urinary 8-oxodGuo/day and renal 8-oxodGuo/ $10^{6} \mathrm{dGuo}$ in $\mathrm{db} / \mathrm{db}$ mice $(r=0.568, P<0.01)$. (c) Correlation between urinary 8 -oxoGuo/day and renal 8 -oxoGuo/10 6 Guo in $\mathrm{db} / \mathrm{m} \mathrm{mice}$ $(r=0.542, P<0.05)$. (d) Correlation between urinary 8 -oxoGuo/day and renal 8 -oxoGuo/10 6 Guo in $\mathrm{db} / \mathrm{db}$ mice $(r=0.661, P<0.01)$.

respectively. The combination of the above parameters with urinary 8-oxodGuo is a confirmed and widely investigated biomarker of diabetic nephropathy, and the ratios of 8oxoGuo to 8-oxodGuo in renal tissue and urine were considerably high in $\mathrm{db} / \mathrm{db}$ mice. We therefore propose that urinary 8-oxoGuo may also be a novel, noninvasive, and easily detected biomarker of DKD. However, caution should be practiced when interpreting these results, as our study was unable to differentiate the causal relationship of 8-oxodGuo and 8-oxoGuo between urine and renal tissue.

It is very important to emphasize the early identification, prevention, and treatment of $\mathrm{DKD}$, since individuals with DKD are at significant risk of progression to end-stage renal disease (ESRD) and cardiovascular morbidity and mortality [28]. Reactive oxygen species (ROS) production in diabetes may be a common pathway linking diverse pathogenic mechanisms of diabetic vascular complications. Therefore, the assessment of oxidative stress in diabetic patients may be important for the prediction and prevention of diabetic complications. To determine whether or not DNA/RNA oxidation is related to the early stage of renal lesions in diabetic nephropathy, we further investigated the relationship between urinary microalbumin and 8-oxodGuo or 8-oxoGuo in the kidney or urine. Renal 8-oxodGuo or 8-oxoGuo levels were found to be closely related to the increase in urinary microalbumin levels, and we also noted significant correlations between 8-oxodGuo or 8-oxoGuo and microalbumin in urine. Furthermore, the increases in 8-oxodGuo or 8-oxoGuo paralleled the aggravation of diabetic nephropathy in $\mathrm{db} / \mathrm{db}$ mice at 4 to 16 weeks of age.

Most previous investigations have analyzed the relationship between 8-oxodGuo, a marker of DNA oxidation, and DKD [5, 6, 20-22], even though RNA is known to be more prone to oxidation than DNA. The low level of interest in RNA oxidation over the years is likely the reason why RNA oxidation has only recently being recognized as a diseaserelevant mechanism [29]. In fact, the oxidation of RNA is minimally determined by genetic factors which may leave ample room for therapeutic interventions [29,30]. Oxidized RNA is recently found in a large variety of diseases and is 


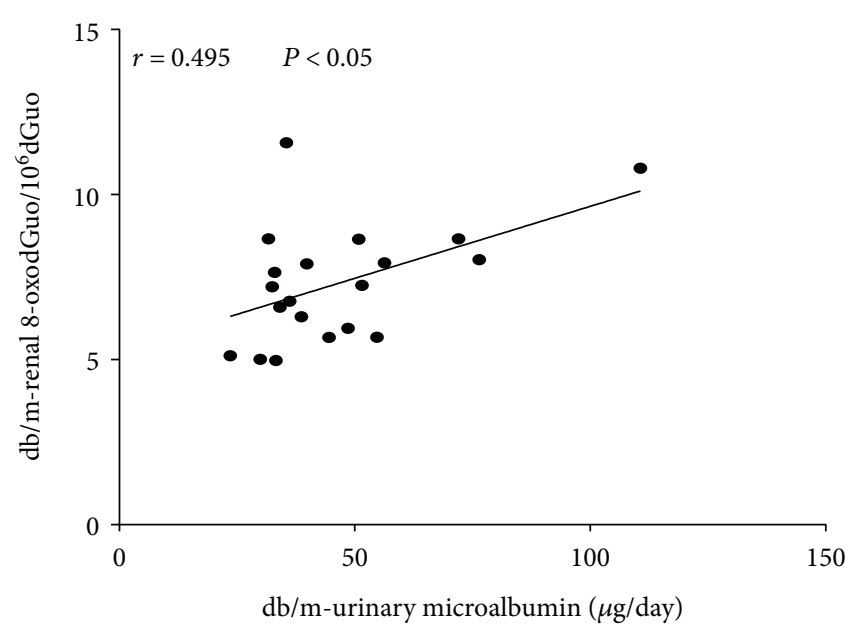

(a)

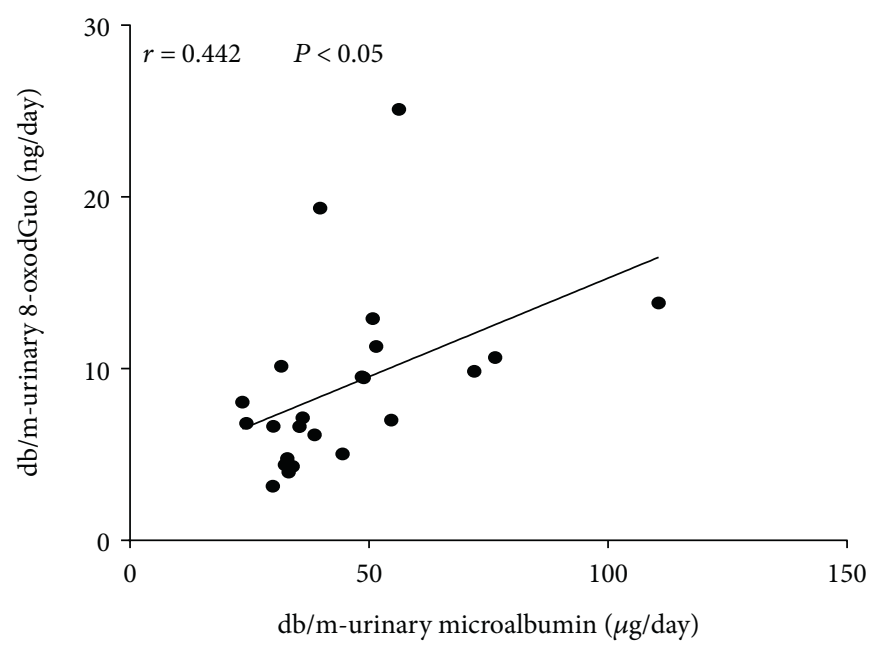

(c)

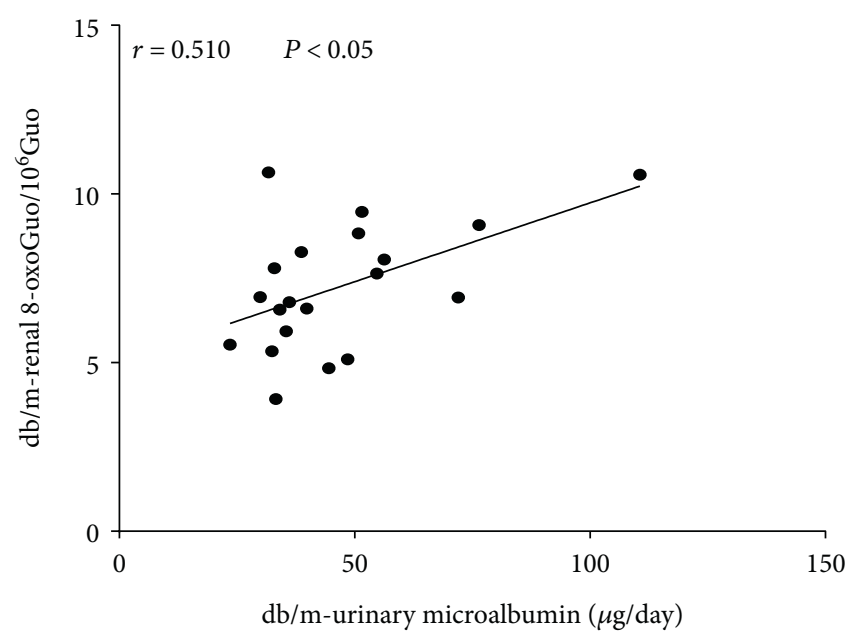

(e)

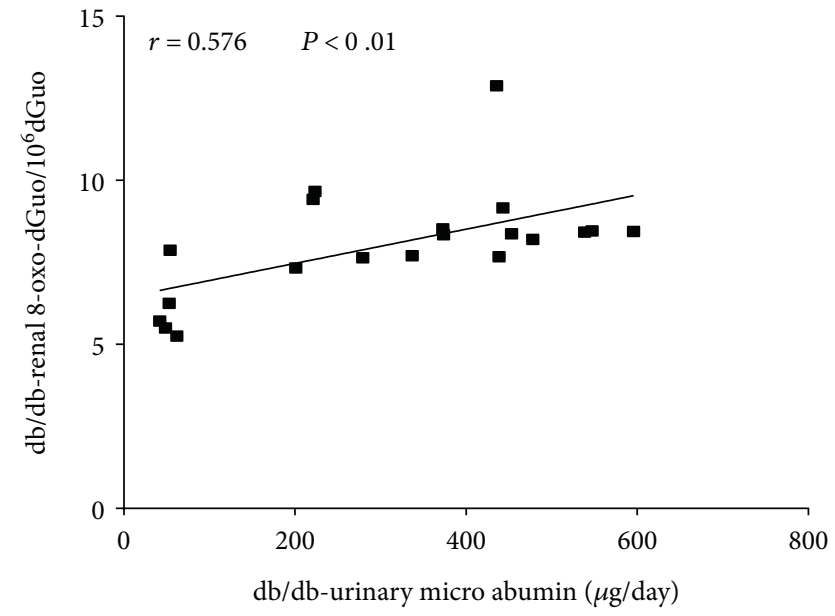

(b)

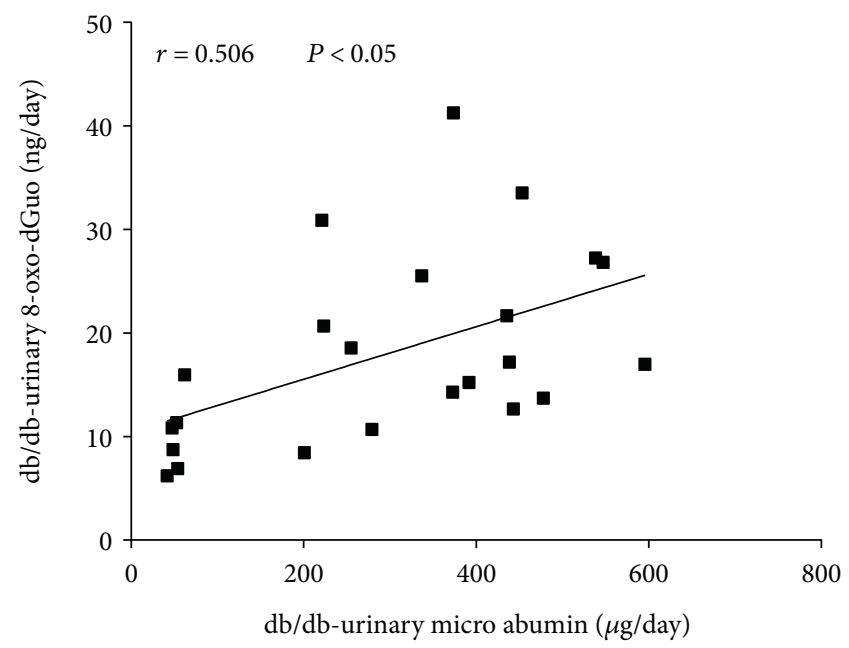

(d)

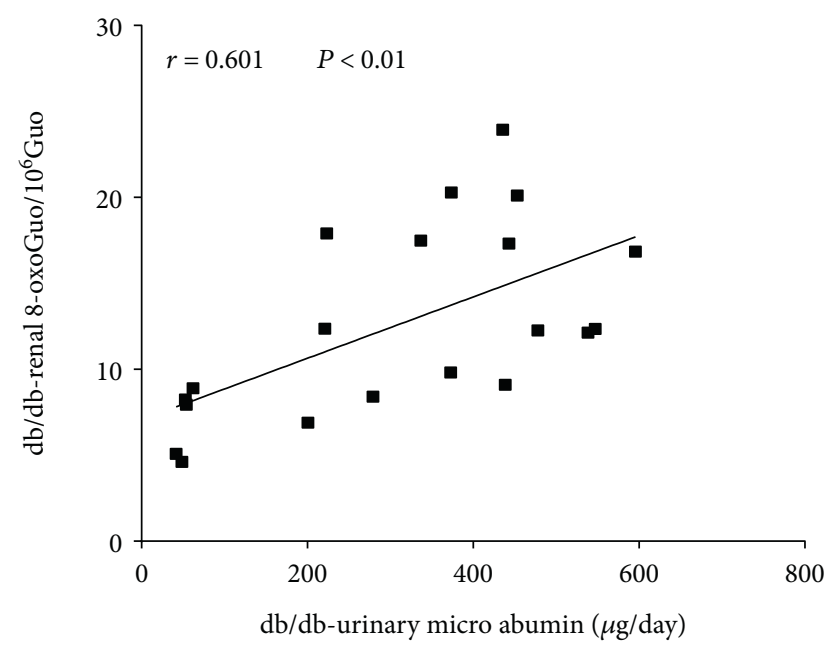

(f)

FIgure 6: Continued. 


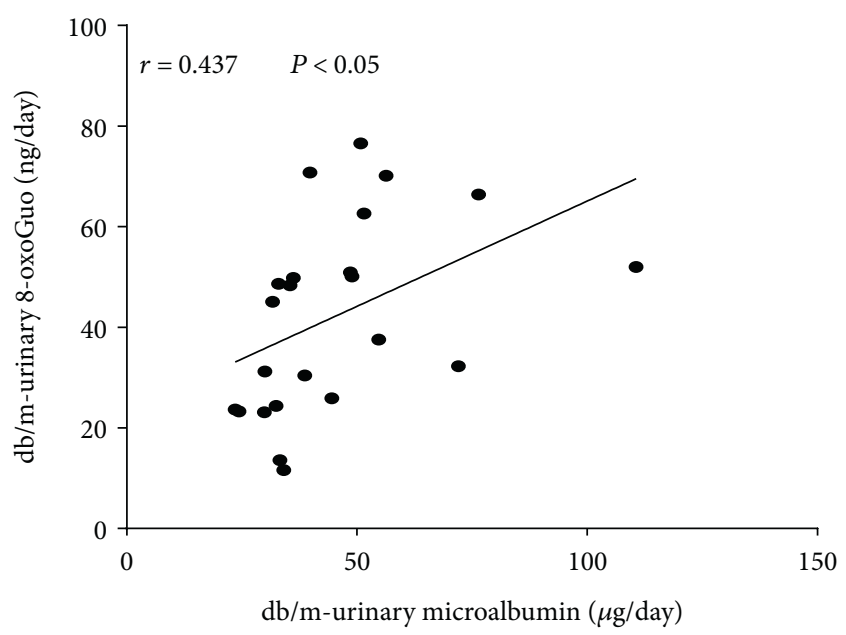

(g)

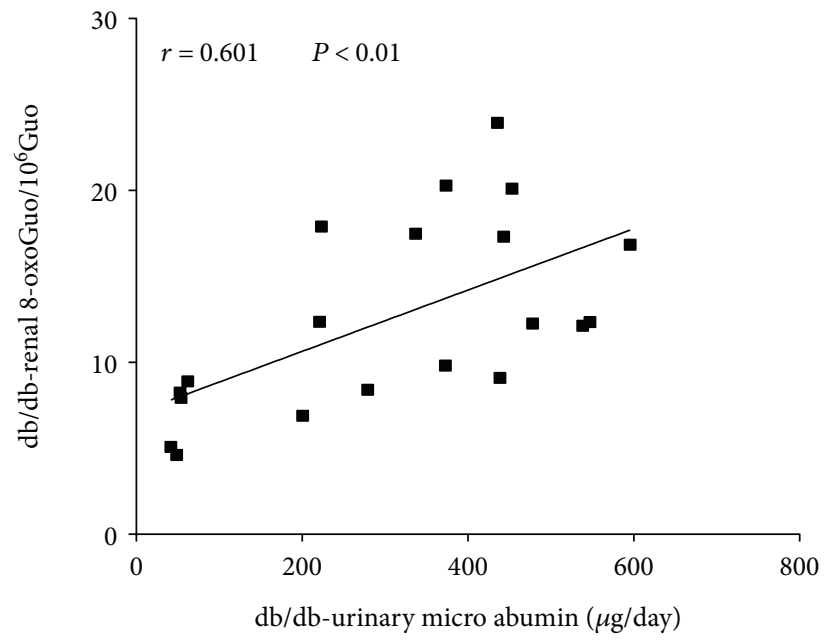

(h)

FIGURE 6: Correlations between 8-oxoGuo/ 8-oxodGuo and urinary microalbumin. (a) Correlation between renal 8-oxodGuo/10 ${ }^{6} \mathrm{dGuo}$ and urinary micro-albumin/day in $\mathrm{db} / \mathrm{m}$ mice $(r=0.495, P<0.05)$. (b) Correlation between renal 8 -oxodGuo/10 ${ }^{6} \mathrm{dGuo}$ and urinary microalbumin/day in $\mathrm{db} / \mathrm{db}$ mice $(r=0.576, P<0.01)$. (c) Correlation between 8 -oxodGuo and microalbumin per day in urine from $\mathrm{db} / \mathrm{m}$ mice $(r=0.442, P<0.05)$. (d) Correlation between 8-oxodGuo and micro-albumin per day in urine from $\mathrm{db} / \mathrm{db}$ mice $(r=0.506, P<0.05)$. (e) Correlation between renal 8 -oxoGuo/ $10^{6}$ Guo and urinary micro-albumin/day in $\mathrm{db} / \mathrm{m}$ mice $(r=0.510, P<0.05)$. (f) Correlation between renal 8-oxoGuo $/ 10^{6} \mathrm{Guo}$ and urinary micro-albumin/day in $\mathrm{db} / \mathrm{db}$ mice $(r=0.601, P<0.01)$. (g) Correlation between 8 -oxoGuo and micro-albumin per day in urine from $\mathrm{db} / \mathrm{m}$ mice $(r=0.437, P<0.05)$. (h) Correlation between 8 -oxoGuo and microalbumin per day in urine from $\mathrm{db} / \mathrm{db}$ mice $(r=0.701, P<0.01)$.

viewed as an early event in some diseases $[9,10]$. Broedbaek et al. found that urinary 8-oxoGuo excretion could predict overall death and death from complications in type 2 diabetes, while urinary 8-oxodGuo could not $[11,31]$. Our previous study also indicated that there were only 8oxoGuo that had significant differences between diabetes patients with complications and those without complications [12]. However, the utility of urinary 8-oxoGuo as an indicator reflecting oxidative damage in the kidney remains unclear.

The present study showed that 8-oxoGuo was more closely related to the levels of urinary microalbumin and early pathological changes of diabetic nephropathy than 8-oxodGuo. A glomerular ultrastructure examination showed that podocyte effacement was more apparent in 4 -week-old $\mathrm{db} / \mathrm{db}$ mice than in their lean littermates. However, only the levels of 8-oxoGuo in the kidney were elevated in 4-week-old $\mathrm{db} / \mathrm{db}$ mice compared with their lean littermates. Although 4-week-old db/db mice showed greater amounts of urinary 8-oxodGuo and 8-oxoGuo than controls, the elevation of 8-oxoGuo in the urine and kidney was greater and appeared earlier than that of 8-oxodGuo, especially in the renal tissue. Multiple linear regression analysis of microalbumin and nucleotide acid oxidation markers also identified urinary 8-oxoGuo as the predominant indicator of the severity of microalbuminuria. These results indicate that RNA oxidation is more apparent and more closely related to early diabetic nephropathy than DNA oxidation. If the source of urinary 8-oxoGuo could be clarified, it might provide new insight into the pathogenesis of diabetic nephropathy. Further studies are needed to investigate the mechanisms of RNA oxidation in the development of DKD and confirm them in large population studies.

\section{Conclusion}

The present study showed that RNA oxidation occurs earlier and is more closely related to early diabetic nephropathy than DNA oxidation in $\mathrm{db} / \mathrm{db}$ mice. Urinary 8-oxoGuo may represent a novel, noninvasive, and easily detected biomarker of diabetic kidney diseases if these results could be confirmed in large population studies. Oxidative damage of RNA may provide new insight into the pathogenesis of diabetic nephropathy. Further studies should investigate the mechanism underlying the association between RNA oxidation and diabetic nephropathy.

\section{Conflicts of Interest}

The authors declare that they have no conflicts of interest.

\section{Authors' Contributions}

Wan-Xia Wang and Shun-Bin Luo contributed equally to this work.

\section{Acknowledgments}

The authors are grateful to the members of the Institute of Geriatrics of the Ministry of Health for their assistance and advice. This work was supported by the National Natural Science Foundation of China (Grant nos. 81171028 and 81571058) and the Gansu Provincial Science \& Technology Program of China (Grant no. 17JR5RA036). 


\section{References}

[1] K. Reidy, H. M. Kang, T. Hostetter, and K. Susztak, "Molecular mechanisms of diabetic kidney disease," The Journal of Clinical Investigation, vol. 124, pp. 2333-2340, 2014.

[2] M. Afkarian, M. C. Sachs, B. Kestenbaum et al., "Kidney disease and increased mortality risk in type 2 diabetes," Journal of the American Society of Nephrology, vol. 24, pp. 302-308, 2013.

[3] S. S. Badal and F. R. Danesh, "New insights into molecular mechanisms of diabetic kidney disease," American Journal of Kidney Diseases, vol. 63, pp. S63-S83, 2014.

[4] G. W. Xu, Q. H. Yao, Q. F. Weng, B. L. Su, X. Zhang, and J. H. Xiong, "Study of urinary 8-hydroxydeoxyguanosine as a biomarker of oxidative DNA damage in diabetic nephropathy patients," Journal of Pharmaceutical and Biomedical Analysis, vol. 36, pp. 101-104, 2004.

[5] T. Nishikawa, T. Sasahara, S. Kiritoshi et al., "Evaluation of urinary 8-hydroxydeoxy-guanosine as a novel biomarker of macrovascular complications in type 2 diabetes," Diabetes Care, vol. 26, pp. 1507-1512, 2003.

[6] Y. Hinokio, S. Suzuki, M. Hirai, C. Suzuki, M. Suzuki, and T. Toyota, "Urinary excretion of 8-oxo-7, 8-dihydro-2'-deoxyguanosine as a predictor of the development of diabetic nephropathy," Diabetologia, vol. 45, pp. 877-882, 2002.

[7] Y. Hinokio, S. Suzuki, M. Hirai, M. Chiba, A. Hirai, and T. Toyota, "Oxidative DNA damage in diabetes mellitus: its association with diabetic complications," Diabetologia, vol. 42, pp. 995-998, 1999.

[8] M. Serdar, E. Sertoglu, M. Uyanik et al., "Comparison of 8-hydroxy-2'-deoxyguanosine (8-OHdG) levels using mass spectrometer and urine albumin creatinine ratio as a predictor of development of diabetic nephropathy," Free Radical Research, vol. 46, pp. 1291-1295, 2012.

[9] Y. Chang, Q. Kong, X. Shan et al., "Messenger RNA oxidation occurs early in disease pathogenesis and promotes motor neuron degeneration in ALS," PLoS One, vol. 3, article e2849, 2008.

[10] X. Shan, Y. Chang, and C. L. Lin, "Messenger RNA oxidation is an early event preceding cell death and causes reduced protein expression," FASEB Journal, vol. 21, pp. 2753-2764, 2007.

[11] K. Broedbaek, V. Siersma, T. Henriksen et al., "Association between urinary markers of nucleic acid oxidation and mortality in type 2 diabetes: a population-based cohort study," Diabetes Care, vol. 36, pp. 669-676, 2013.

[12] X. Liu, W. Gan, Y. Zou, and B. Yang, "Elevated levels of urinary markers of oxidative dna and RNA damage in type 2 diabetes with complications," Oxidative Medicine and Cellular Longevity, vol. 2016, Article ID 4323198, 7 pages, 2016.

[13] W. X. Wang, S. B. Luo, M. M. Xia et al., "Analysis of the oxidative damage of DNA, RNA, and their metabolites induced by hyperglycemia and related nephropathy in Sprague Dawley rats," Free Radical Research, vol. 49, pp. 1-31, 2015.

[14] F. C. Brosius 3rd, C. E. Alpers, E. P. Bottinger et al., "Mouse models of diabetic nephropathy," Journal of the American Society of Nephrology, vol. 20, pp. 2503-2512, 2009.

[15] M. D. Breyer, E. Bottinger, F. C. Brosius 3rd et al., "Mouse models of diabetic nephropathy," Journal of the American Society of Nephrology, vol. 16, pp. 27-45, 2005.

[16] W. Gan, B. Nie, F. Shi et al., "Age-dependent increases in the oxidative damage of DNA, RNA, and their metabolites in normal and senescence-accelerated mice analyzed by LC-MS/MS:
Urinary 8-oxoguanosine as a novel biomarker of aging," Free Radical Biology \& Medicine, vol. 52, pp. 1700-1707, 2012.

[17] J. M. Teiken, P. N. Epstein, and E. C. Carlson, “TEM stereometric analyses of glomeruli in aging OVE26 transgenic diabetic mice," American Journal of Nephrology, vol. 33, Supplement 1, pp. 8-14, 2011.

[18] S. H. Sung, F. N. Ziyadeh, A. Wang, P. E. Pyagay, Y. S. Kanwar, and S. Chen, "Blockade of vascular endothelial growth factor signaling ameliorates diabetic albuminuria in mice," Journal of the American Society of Nephrology, vol. 17, pp. 30933104, 2006.

[19] European Standards Committee on Oxidative DNA Damage (ESCODD), "Measurement of DNA oxidation in human cells by chromatographic and enzymic methods," Free Radical Biology \& Medicine, vol. 34, pp. 1089-1099, 2003.

[20] S. Yoshida, T. Hashimoto, M. Kihara et al., "Urinary oxidative stress markers closely reflect the efficacy of candesartan treatment for diabetic nephropathy," Nephron Experimental Nephrology, vol. 111, pp. e20-e30, 2009.

[21] S. Prabhakar, J. Starnes, S. Shi, B. Lonis, and R. Tran, "Diabetic nephropathy is associated with oxidative stress and decreased renal nitric oxide production," Journal of the American Society of Nephrology, vol. 18, pp. 2945-2952, 2007.

[22] M. Kakimoto, T. Inoguchi, T. Sonta et al., "Accumulation of 8-hydroxy-2'-deoxyguanosine and mitochondrial DNA deletion in kidney of diabetic rats," Diabetes, vol. 51, pp. 15881595, 2002.

[23] P. Rossner Jr., H. Orhan, G. Koppen et al., "Urinary 8-oxo7,8-dihydro-2'-deoxyguanosine analysis by an improved ELISA: an inter-laboratory comparison study," Free Radical Biology \& Medicine, vol. 95, pp. 169-179, 2016.

[24] H. E. Poulsen, L. L. Nadal, K. Broedbaek, P. E. Nielsen, and A. Weimann, "Detection and interpretation of 8-oxodG and 8-oxoGua in urine, plasma and cerebrospinal fluid," Biochimica et Biophysica Acta (BBA) - General Subjects, vol. 1840, 2014.

[25] C. W. Hu, M. R. Chao, and C. H. Sie, "Urinary analysis of 8-oxo-7,8-dihydroguanine and 8-oxo-7,8-dihydro-2'-deoxyguanosine by isotope-dilution LC-MS/MS with automated solid-phase extraction: Study of 8-oxo-7,8-dihydroguanine stability," Free Radical Biology \& Medicine, vol. 48, pp. 89-97, 2010.

[26] R. Andreoli, P. Manini, G. De Palma et al., "Quantitative determination of urinary 8-oxo-7,8-dihydro-2'-deoxyguanosine, 8-oxo-7,8-dihydroguanine, 8-oxo-7,8-dihydroguanosine, and their non-oxidized forms: daily concentration profile in healthy volunteers," Biomarkers, vol. 15, pp. 221-231, 2010.

[27] A. Weimann, D. Belling, and H. E. Poulsen, "Quantification of 8-oxo-guanine and guanine as the nucleobase, nucleoside and deoxynucleoside forms in human urine by highperformance liquid chromatography-electrospray tandem mass spectrometry," Nucleic Acids Research, vol. 30, article E7, 2002.

[28] R. J. Macisaac, E. I. Ekinci, and G. Jerums, "Markers of and risk factors for the development and progression of diabetic kidney disease," American Journal of Kidney Diseases, vol. 63, pp. S39-S62, 2014.

[29] H. E. Poulsen, E. Specht, K. Broedbaek et al., "RNA modifications by oxidation: a novel disease mechanism?," Free Radical Biology \& Medicine, vol. 52, pp. 1353-1361, 2012. 
[30] K. Broedbaek, R. Ribel-Madsen, T. Henriksen et al., "Genetic and environmental influences on oxidative damage assessed in elderly Danish twins," Free Radical Biology \& Medicine, vol. 50, pp. 1488-1491, 2011.

[31] K. Broedbaek, V. Siersma, T. Henriksen et al., "Urinary markers of nucleic acid oxidation and long-term mortality of newly diagnosed type 2 diabetic patients," Diabetes Care, vol. 34, pp. 2594-2596, 2011. 


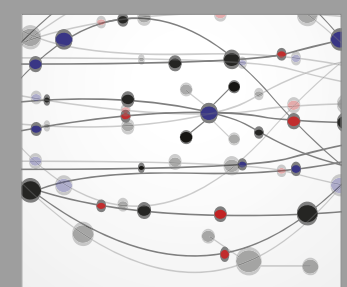

The Scientific World Journal
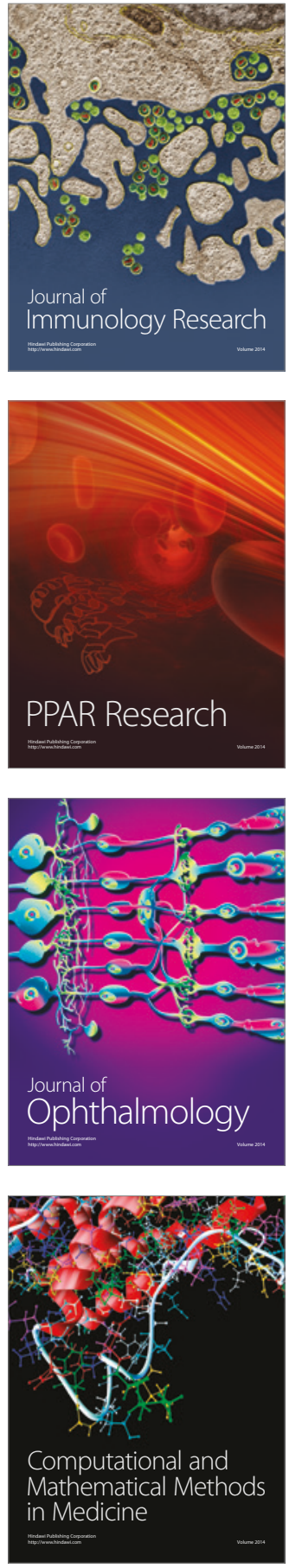

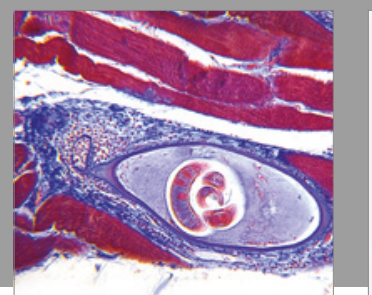

Gastroenterology Research and Practice
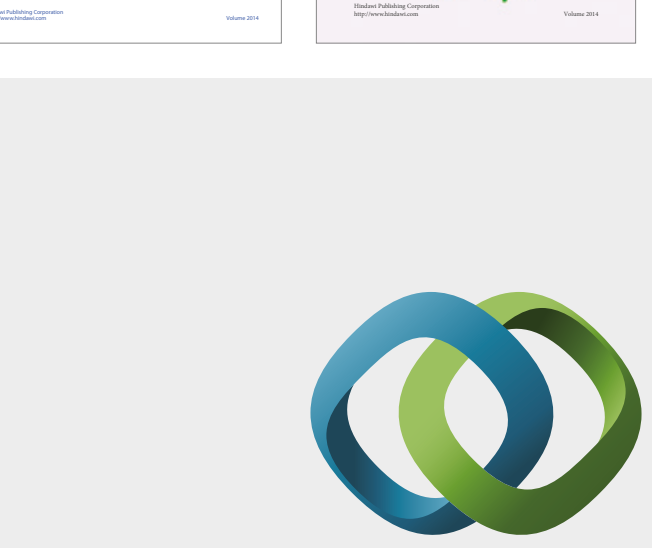

\section{Hindawi}

Submit your manuscripts at

https://www.hindawi.com
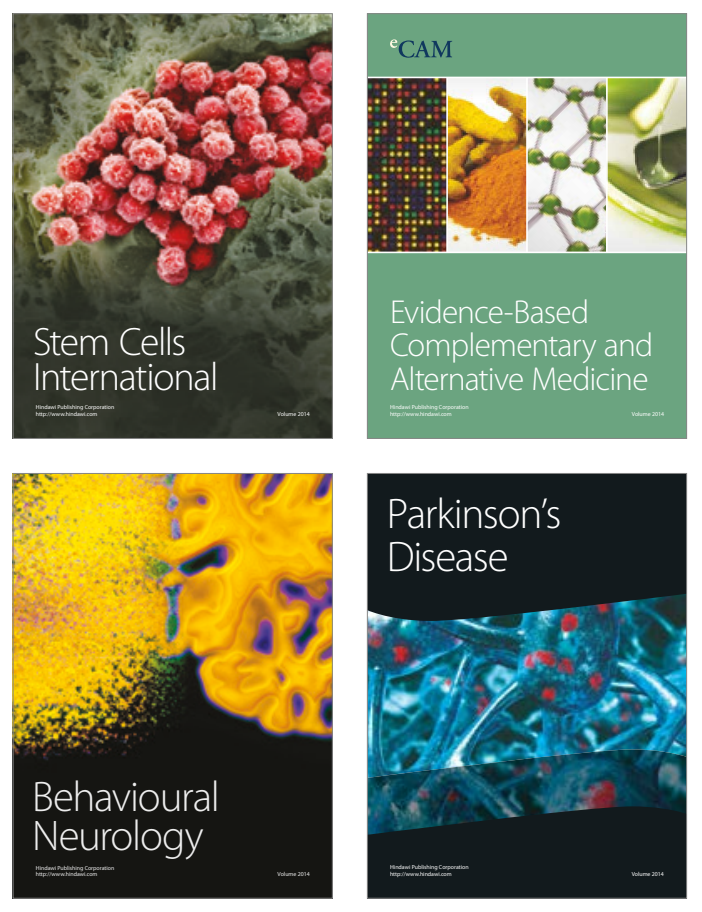
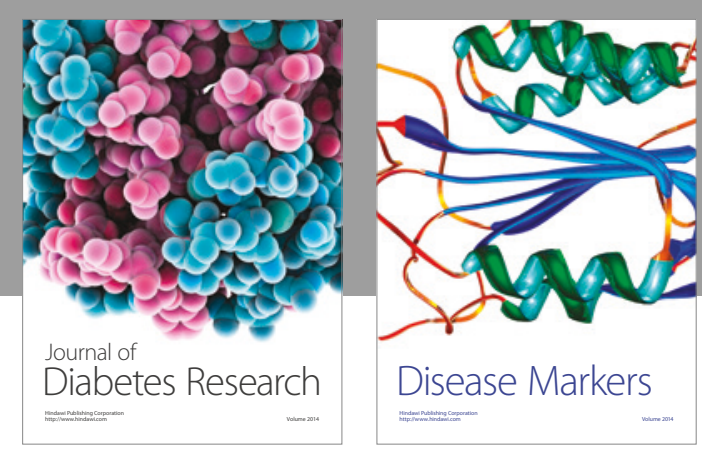

Disease Markers
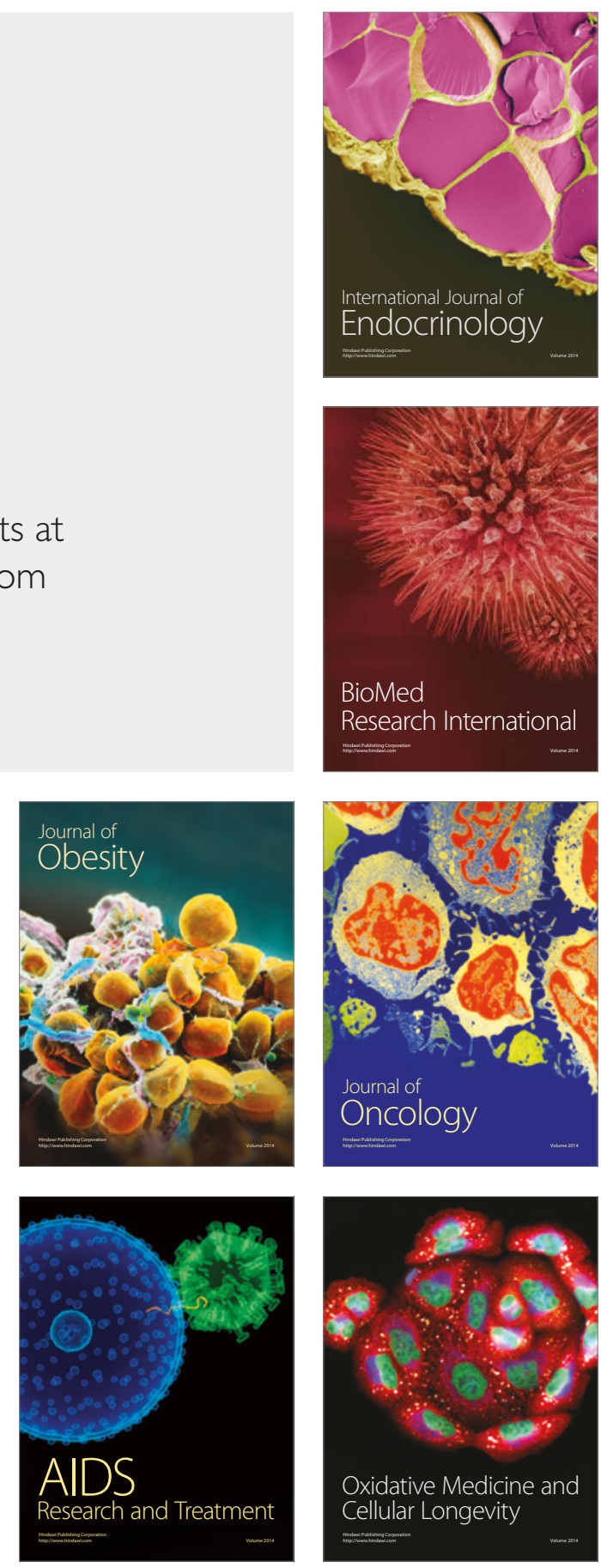